\title{
KEBIJAKAN PERUBAHAN SNI BERAS DALAM PEMBUKTIAN TINDAK PIDANA MENGEDARKAN DAN MEMPERJUALBELIKAN BERAS CAMPUR DALAM HUKUM PERLINDUNGAN KONSUMEN
}

\author{
Prihadi Tri Saputra \\ prihaditris@gmail.com
}

Ditreskrimsus Polda Riau

\section{ABSTRACT}

This study aims to analyze the Proof of Circulating Crime, and Buy and Sell Mixed Rice and the Policy on SNI Change of Rice from Voluntary to Obligatory in Proving Criminal Circulation and Buying and Selling Mixed Rice Associated with Consumer Protection Efforts. The results showed that Proof of Circulating Crime, and Buying and Selling Rice Mix that the investigation carried out by Investigators in the context of handling criminal cases of consumer protection in this case circulating and trading mixed rice can be continued due to the discovery of evidence in the form of agreement documents from the parties, regulations governing circulating and trading mixed rice that have not provided legal certainty so that efforts to provide protection to the public, especially consumers in the matter of circulating and trading mixed rice

Keywords: Policy, Criminal Acts, Consumer Protection Law

\section{ABSTRAK}

Penelitian ini bertujuan untuk menganalisis Pembuktian Tindak Pidana Mengedarkan, dan Memperjualbelikan Beras Campur dan Kebijakan Perubahan SNI Beras Dari Sukarela Menjadi Wajib Dalam Pembuktian Tindak Pidana Mengedarkan dan Memperjualbelikan Beras Campur Dikaitkan Dengan Upaya Perlindungan Konsumen. Hasil penelitian menunjukkan bahwa Pembuktian Tindak Pidana Mengedarkan, dan Memperjualbelikan Beras Campur bahwa penyidikan yang telah dilakukan oleh Penyidik dalam rangka penanganan perkara tindak pidana perlindungan konsumen dalam hal ini mengedarkan dan memperjualbelikan beras campur dapat dilanjutkan dikarenakan ditemukannya alat bukti berupa adanya dokumen perjanjian dari para pihak, peraturan yang mengatur tentang mengedarkan dan memperjualbelikan beras campur yang belum memberikan kepastian hukum sehingga upaya dalam memberikan perlindungan terhadap masyarakat khususnya konsumen dalam hal mengedarkan dan memperjualbelikan beras campur

\section{Kata kunci: Kebijakan, Tindak Pidana, Hukum Perlindungan Konsumen}




\section{PENDAHULUAN}

Negara Indonesia adalah Negara hukum. Pengertian negara hukum secara sederhana adalah negara yang menyelenggarakan kekuasaan pemerintahannya berdasarkan hukum. Dalam Undang-undang Dasar Negara Kesatuan Republik Indonesia Tahun 1945 Pasal 3 ayat (1) disebutkan bahwa "Negara Indonesia adalah Negara hukum". Dalam penjelasan Undangundang Dasar Negara Republik Indonesia Tahun 1945 tersebut dijelaskan bahwa "Negara Indonesia berdasarkan atas hukum (rechtstaat) tidak berdasarkan kekuasaan belaka (machstaat). Oleh karena itu Negara tidak boleh melaksanakan aktivitasnya atas dasar kekuasaan belaka, tetapi harus berdasarkan pada hukum. ${ }^{1}$

Hukum pidana di Indonesia dibagi menjadi dua, yaitu hukum pidana umum dan hukum pidana khusus. Hukum pidana umum sebagaimana tercantum dalam KUHP, sedangkan hukum pidana khusus bisa dimaknai sebagai perundangundangan di bidang tertentu yang memiliki sanksi pidana, atau tindaktindak pidana yang diatur dalam

\footnotetext{
${ }^{1}$ C.S.T Kansil, dan Christine S.T. Kansil, Hukum dan Tata Negara Republik Indonesia, Cetakan Ketiga, Rineka Cipta, Jakarta, 2002, hal. 90.
}

perundang-undangan khusus, di luar KUHP.

Bentuk tindak pidana khusus antara lain : Tindak Pidana Korupsi, Tindak Pidana Pencucian Uang, Tindak Pidana Perpajakan, Tindak Pidana Perbankan, Tindak Pidana Terorisme, Tindak Pidana di Bidang Lingkungan Hidup, Tindak Pidana dibidang Kepabeanan, Tindak Pidana dibidang Konsumen dan lain-lain. Salah satu tindak pidana khusus yang akan dibahas dalam penelitian ini adalah Tindak Pidana dibidang Konsumen, yang lebih dikhususkan lagi yaitu tindak pidana mengedarkan dan memperjualbelikan beras campur (beras yang bagus dicampur dengan yang beras yang rusak).

\section{Perkembangan perekonomian} yang pesat telah menghasilkan berbagai jenis dan variasi dari masing-masing jenis barang yang dapat dikonsumsi oleh masyarakat luas sebagai kebutuhan sehari-hari. Kondisi seperti itu, di satu sisi memberikan manfaat bagi konsumen karena kebutuhan akan barang yang diinginkan dapat terpenuhi, serta semakin terbuka lebar kebebasan untuk memilih aneka jenis dan kualitas barang sesuai dengan keinginan dan kemampuan konsumen. Namun, di sisi lain kondisi seperti itu dapat mengakibatkan 
kedudukan pelaku usaha dan konsumen menjadi tidak seimbang.

Hubungan yang terjalin antara pelaku usaha dengan konsumen tidak selalu menunjukkan hubungan yang positif. Adanya perselisihan yang mewarnai hubungan antara pelaku usaha dengan konsumen kerap terjadi. Salah satu faktor yang menjadi pemicu perselisihan tersebut dikarenakan ketidakseimbangan kedudukan antara pelaku usaha dengan konsumen yang juga tidak diikuti dengan kesigapan pemerintah dalam membentuk suatu peraturan yang menangani permasalahan tersebut. Konsumen menjadi korban yang sangat potensial di tengah proses perdagangan, untuk itu Pelaku usaha dituntut untuk selalu memperbaiki produk mereka dan tetap menjaga tanggungjawabnya atas setiap komoditi yang dihasilkan (product liability). ${ }^{2}$

Pelaku usaha memegang prinsip ekonomi yang tentu saja semakin menyudutkan posisi konsumen. Dengan modal yang sekecil-kecilnya pelaku usaha ingin mendapatkan keuntungan yang sebesar-besarnya. Sementara keadaan ekonomi masyarakat sebagai konsumen

\footnotetext{
${ }^{2}$ Husni Syawali, dan Neni Sri Imaniyani, Hukum Perlindungan Konsumen, Bandung, Mandar Maju, 2000, hal. 13
}

tidak memungkinkan untuk mengikut inya. Pelaku usaha sering tidak memikirkan keadaan mutu barang yang dihasilkan demi memperkaya diri sendiri dan membiarkan konsumen terus dalam keterpurukan dengan terus menerima apapun resiko dari pelaku usaha tersebut. Konsumen menjadi objek aktivitas bisnis untuk meraup keuntungan yang sebesarbesarnya oleh pelaku usaha melalui kiat promosi $^{3}$, cara penjualan, serta penerapan perjanjian standar yang merugikan konsumen.

Perlindungan

merupakan masalah kepentingan manusia, oleh karenanya menjadi harapan bagi seluruh masyarakat untuk dapat menikmatinya. Mewujudkan perlindungan konsumen adalah mewujudkan hubungan berbagai dimensi dimana antara yang satu dengan yang lainnya mempunyai keterkaitan dan saling ketergantungan antara konsumen, pelaku usaha dan pemerintah. Permasalahan di bidang perlindungan konsumen yang pernah terangkat ke permukaan, menambah panjang deretan

\footnotetext{
3 Ahmadi Miru \& Sutarman Yodo, Hukum Perlindungan Konsumen, PT Raja Grafindo Persada, Jakarta, 2004, hal. 9
} 
kasus di bidang perlindungan konsumen itu sendiri ${ }^{4}$.

Permasalahan sengketa juga sering ada yang menjurus kepada perbuatan pidana yang disebabkan ulah pelaku usaha yang tidak sportif dan bertanggungjawab dalam menjalankan kegiatan usahanya, misalanya seperti perkara yang penulis angkat ini, tentang tindak pidana menjual/mengedarkan beras yang tidak layak konsumsi/beras campur sehingga menyebabkan masyarakat yang memakannya karena tidak enak dan pasti merugikan konsumen.

\section{METODE PENELITIAN}

Jenis penelitian yang digunakan dalam pokok permasalahan ini adalah penelitian Hukum Normatif Empiris, hal ini dimaksudkan agar peneliti sejauh mungkin dapat mengetahui apa yang menjadi alat ukur dalam membahas penelitian ini, sehingga dapat mencari setitik kebenaran tujuan dalam penelitian ini. Obyek dari penelitian penulis ini berkenaan dengan tindak pidana mengedarkan beras campur di wilayah hukum Direktorat Kriminal Khusus Polda Riau.

\footnotetext{
4 Happy Susanto, Hak-Hak Konsumen Jika Dirugikan, Visimedia, Jakarta, 2008, hal. 6
}

Penelitian hukum dengan menggunakan metode penelitian normatif yaitu dengan menganalisis data seeara kualitatif dengan cara menganalisis bahan-bahan hukum yang telah terkumpul dan mengelolah secara sistematis. Sistematisasi berarti membuat klasifikasi terhadap bahan-bahan hukum tersebut dengan mengunakan analisis kualitatif. Analisis secara kualitatif dimaksudkan dengan menganalisis data berdasarkan pandangan teori dan bahan hukum yang ada maka dapat ditarik kesimpulan sehingga dapat dikemukakan yang perlu dalam penelitan ini. Kemudian penulis mengambil kesimpulan dengan menggunakan metode induktif yaitu mengambil kesimpulan dari hal-hal yang bersifat khusus terhadap hal-hal yang bersifat umum.

\section{HASIL PENELITIAN}

\section{A. Problematika Penyidik Dalam Pembuktian Tindak Pidana Mengedarkan dan Memperjualbelikan beras campur}

Kepolisian merupakan salah satu aparat penegak hukum yang mempunyai kewenangan melakukan tugas penyelidikan dan penyidikan untuk semua perkara pidana (lihat Pasal 13 UU Nomor 
2 Tahun 2002 tentang Kepolisian, selanjutnya disebut UU Kepolisian) dan atas dasar itu aparat kepolisian dituntut untuk dapat mengembangkan dirinya sebagai aparat hukum profesional yang mampu menerapkan hukum positif dalam kasus yang konkrit. Peningkatan sumber daya manusia dalam kepolisian tidak dapat ditunda-tunda lagi dengan percepatan munculnya aturan-aturan baru, adanya perubahan aturan, kompleksitas modus operandi kejahatan, dan jika hal tersebut tidak dilakukan maka niscaya penegakan hukum dapat berjalan sebagaimana mestinya.

Pengungkapan suatu kejahatan kadang-kadang tidaklah mudah seperti yang dibayangkan, meskipun demikian aparat penegak hukum harus dapat dengan piawai mengungkap kejahatan, tanpa harus melakukan kekerasan atau penyiksaan. Penyidik janganlah mengejar pengakuan tersangka, melainkan yang dicari adalah alat bukti yang sah dan barang bukti yang mendukung kebenaran atas perbuatan yang dilakukan tersangka. Kasus mengedarkan dan memperjualbelikan beras campur yang merugikan konsumen merupakan suatu kesulitan yang dialami oleh penyidik dalam mengungkap kasus tindak pidana ini. Maka diperlukan alat bukti yang sah untuk mengungkap tindak pidana ini, tanpa mempertimbangkan alat bukti dan barang bukti yang mendukung atas perbuatan tersebut. Delik yang dirumuskan secara materiil atau delik yang dikualifisir akibatnya perlu dicari hubungan kausal antara fakta-fakta yang telah dikumpulkan dengan akibat yang terjadi. Jika dalam perkara tersebut tidak ada hubungan kausal, maka penyidik harus membebaskan tersangka.

Perkara pidana yang disidangkan adalah perkara yang melanggar hukum pidana sehingga bagi si pelanggar dapat dijatuhi hukuman. Pada prinsipnya, proses penyelesaian perkara pidana berdasarkan Undang-Undang No. 8 Tahun 1981 dimulai dengan penyelidikan oleh penyelidik. Penyelidik kemudian membuat dan menyampaikan laporan hasil pelaksanaan penyelidikan kepada penyidik. Setelah selesai pemeriksaan oleh penyidik, berkas pemeriksaan diserahkan kepada penuntut umum. Tahap berikutnya adalah proses pemeriksaan perkara pidana di muka sidang pengadilan. Sesuai dengan ketentuan yang diatur oleh Kitab UndangUndang Hukum Acara Pidana. ${ }^{5}$

\footnotetext{
5 Mohammad Taufik Makarao dan Suhansil, Hukum Acara Pidana Dalam Teori dan Praktek, Ghalia Indonesia, Bogor, 2010, hlm. 4
} 
Hukum diyakini sebagai alat untuk memberikan kesebandingan dan kepastian dalam pergaulan hidup. Layaknya suatu alat, hukum akan dibutuhkan jika timbul kebutuhan atau keadaan yang luar biasa di dalam masyarakat. Asas legalitas diman suatu perbuatan belum dianggap sebagai tindak pidana jika perbuatan tersebut tidak secara tegas tercantum di dalam peraturan hukum pidana. KUHP (Kitab UndangUndang Hukum Pidana) atau ketentuan pidana lainnya. Prinsip tersebut hingga sekarang dijadikan pijakan demi terjaminnya kepastian hukum. ${ }^{6}$

Penegakan hukum adalah proses dilakukanya upaya untuk tegaknya atau berfungsinya suatu norma hukum secara nyata sebagai pedoman prilaku dalam lintas hukum atau hubungan-hubungan hukum dalam kehidupan bermasyarakat dan bernegara. ${ }^{7}$

Penyidikan tindak pidana merupakan serangkaian tindakan penyidik dalam hal dan menurut cara yang diatur dalam Undang-Undang Nomor 8 Tahun 1981 tentang Kitab UndangUndang Hukum Acara Pidana. untuk mencari

\footnotetext{
${ }^{6}$ R. Musdalifa, Tinjauan Yuridis Terhadap Tindak Pidana Penggunaan Ijazah Palsu,Grafika, Jakarta 2013, hlm. 1.

7 2http://www.pengertianilmu.com/2015/01/pe ngertian-penegakan-hukum-dalam.html diakses pada tanggal 20 Oktober 2018
}

serta mengumpulkan bukti yang dengan bukti itu membuat terang tentang tindak pidana yang terjadi dan guna menemukan tersangkanya. Penyidikan merupakan suatu tahap terpenting dalam kerangka hukum acara pidana di Indonesia karena dalam tahap ini pihak penyidik berupaya mengungkapkan fakta-fakta dan buktibukti atas terjadinya suatu tindak pidana serta menemukan tersangka pelaku tindak pidana tersebut. $^{8}$

\section{Penyidik adalah orang yang} melakukan penyidikan yang terdiri dari pejabat yaitu pejabat Polisi Negara Republik Indonesia (POLRI) yang terbagi menjadi pejabat penyidik penuh dan pejabat penyidik pembantu, serta pejabat pegawai negeri sipil tertentu yang diberi wewenang khusus oleh undang-undang. Keberhasilan penyidikan suatu tindak pidana akan sangat mempengaruhi berhasil tidaknya penuntutan Jaksa Penuntut Umum (JPU) pada tahap pemeriksaan sidang pengadilan nantinya. ${ }^{9}$

Berdasarkan rumusan Pasal 1 butir 2 KUHAP, unsur-unsur yang terkandung dalam pengertian penyidikan adalah: a.

\footnotetext{
${ }^{8}$ M. Yahya, Harahap, Pembahasan Permasalahan dan Penerapan KUHAP Penyidikan dan Penuntutan (edisi Kedua), Sinar Grafika, Jakarta, 2012, hal. 23.

${ }^{9}$ Hartono, Penyidikan dan Penegakan Hukum Pidana melalui Pendekatan Hukum Progresif, Sinar Grafika, Jakarta, 2010, hal. 9.
} 
Penyidikan merupakan serangkaian tindakan yang mengandung tindakantindakan yang antara satu dengan yang lain saling berhubungan; $b$ Penyidikan dilakukan oleh pejabat publik yang disebut penyidik; c. Penyidikan dilakukan dengan berdasarkan peraturan perundang-undangan.

d. Tujuan penyidikan ialah mencari dan mengumpulkan bukti, yang dengan bukti itu membuat terang tindak pidana yang terjadi, dan menemukan tersangkanya.

Berdasarkan keempat unsur tersebut sebelum dilakukan penyidikan, telah diketahui adanya tindak pidana tetapi tindak pidana itu belum terang dan belum diketahui siapa yang melakukannya. Adanya tindak pidana yang belum terang itu diketahui dari penyelidikannya ${ }^{10}$.

$$
\text { Peranan kepolisian yang }
$$
seharusnya setelah melakukan penyelidikan pihak kepolisian akan melakukan penyidikan untuk mencari bukti-bukti yang dapat meyakinkan atau mendukung keyakinan bahwa tindak pidana itu benar-benar terjadi dan agar menemukan siapa tersangka dalam tindak pidana tersebut.

${ }^{10}$ Adami Chazawi, Hukum Pidana Materiil dan Formil Korupsi di Indonesia, Bayumedia Publishing, 2005, Malang, hal. 380-381.
Peranan kepolisian yang sebenarnya dilakukan dalam penyidikan tindak pidana mengedarkan dan b. memperjualbelikan beras campur itu sendiri mempertimbangkan antara kehendak hukum yang tertulis dengan kenyataan-kenyataan, dalam kehendak ini kehendak hukum harus menentukan kemampuannya berdasarkan kenyataan yang ada, kepolisian melakukan penyidikan untuk mancari barang bukti kemudian bekerjasama dengan kejaksaan lalu melimpahkannya ke pengadilan.

Pemeriksaan yang dilakukan oleh penyidik difokuskan sepanjang hal yang menyangkut persoalan hukum. Titik pangkal pemeriksaan dihadapan penyidik ialah tersangka. Dari dialah diperoleh keterangan mengenai peristiwa pidana yang sedang diperiksa. Akan tetapi, sekalipun tersangka yang menjadi titik tolak pemeriksaan, terhadapnya harus diberlakukan asas akusatur. Tersangka harus ditempatkan pada kedudukan menusia yang memiliki harkat martabat. Dia harus di nilai sebagai subjek, bukan sebagai objek. Adapun yang diperiksa bukan manusia tersangka. Perbuatan tindak pidana yang dilakukannyalah yang menjadi objek pemeriksaan. Pemeriksaan tersebut ditujukan kearah kesalahan tindak pidana yang dilakukan oleh 
tersangka. Tersangka harus dianggap tak bersalah, sesuai dengan prinsip hukum "praduga tak bersalah" (presumption of innocent) sampai diperoleh putusan pengadilan yang telah berkekuatan hukum tetap. ${ }^{11}$

\section{B. Kontruksi Hukum Penyidikan Dalam Pembuktian tindak pidana mengedarkan dan memperjualbelikan beras campur} Masalah pembuktian tindak pidana mengedarkan dan memperjualbelikan beras campur ini merupakan masalah yang pelik (ingewikkeld) dan justru masalah pembuktian menempati titik sentral dalam hukum acara pidana. Adapun tujuan dari pembuktian adalah untuk mencari dan mendapatkan kebenaran materil, dan bukanlah untuk mencari kesalahan seseorang. Pembuktian dalam hukum acara pidana dikenal dengan sistem negatif (negatif wettelijk stelsel) yaitu merupakan sistem dalam penjatuhan pidana oleh hakim haruslah memenuhi dua syarat yaitu Alat bukti yang cukup dan Keyakinan hakim. ${ }^{12}$

\footnotetext{
${ }^{11}$ Anton Tabah, Menetap Dengan Mata Hati Polisi Indonesia, Gramedia Pustaka Utama, 1991, Jakarta, hal 46.

${ }^{12}$ Munir Fuady, Op.Cit, hlm. 2
}

Sebagaimana dalam hukum pembuktian dalam perkara tindak pidana mengedarkan dan memperjualbelikan beras campur alat bukti terdiri dari lima yang pertama yaitu keterangan saksi dan selanjutnya alat bukti tersebut yaitu keterangan dari ahli. Sebagaimana menurut ketentuan Pasal 1 angka 28 KUHAP yang menyatakan "Keterangan ahli adalah keterangan yang diberikan oleh seorang yang memiliki keahlian khusus tentang hal yang diperlukan untuk membuat terang suatu perkara pidana guna kepentingan pemeriksaan.”

Dalam kontruksi pemidaan yang diterapkan oleh penyidik tentunya mengacu terhadap regulasi yang mengaturnya dimana terkait dengan perdagangan beras telah diatur dalam SNI: 6128-2015 yang disesuaikan dengan inpres No 3/2007, yakni:

a. Butir Patah

Beras patah yaitu butir beras sehat maupun cacat dengan ukuran lebih besar atau sama dengan 0,2 sampai dengan lebih kecil 0,8 bagian dari butir beras utuh. Penentuan butir patah dimulai dengan mengambil sampel sebanyak 100 gram beras. Butir patah dipisahkan dengan beras kepala menggunakan rice grader. Butir patah dipisahkan dengan 
menggunakan ayakan $2,0 \mathrm{~mm}$ atau menggunakan pinset dan kaca pembesar secara visual. Prosentase beras patah ditunjukkan pada persamaan dengan rumus

b. Butir menir

Butir menir yaitu butir beras sehat maupun cacat yang mempunyai ukuran lebih kecil dari 0,2 bagian butir beras utuh. Penentuan butir menir diawali dengan pengambilan sampel sebanyak 100 gram beras. Butir menir dipisahkan dengan beras kepala menggunakan rice grader. Butir menir dipisahkan menggunakan pinset dan kaca pembesar secara visual

c. Butir Kuning

Butir kuning yaitu butir beras utuh, beras kepala, beras patah, dan menir yang berwarna kuning, kuning kecoklatan, atau kuning semu akibat proses fsik atau aktifitas mikroorganisme. Penentuan butir kuning atau rusak dilakukan dengan cara mengambil sampel sebanyak 100 gram beras, kemudian dipisahkan secara visual menggunakan pinset dan kaca pembesar. Persamaan 3 menunjukkan perhitungan kadar butir kuning

d. Derajat Sosoh
Derajat sosoh yaitu tingkat terlepasnya lapisan perikarp, testa, dan aleuron serta lembaga dari tiap butir beras. Derajat sosoh $95 \%$ merupakan tingkat terlepasnya lapisan perikarp, testa, dan aleuron dari butir beras sehingga sisa yang belum terlepas sebesar 5\%. Derajat sosoh dapat ditentukan secara kualitatif dan kuantitatif. Penentuan derajat sosoh secara kuantitatif dikenal dengan metode konversi, yakni menggunakan alat pengukur derajat putih. Nilai derajat sosoh ditentukan dari hasil prosentase derajat putih yang dikonversikan.

Ukuran beras dipengaruhi oleh panjang butir beras, dan lebar butir beras. Panjang butir beras diukur antara dua ujung butir beras utuh. Bentuk beras ditentukan oleh nilai rasio panjang $(\mathrm{P})$ terhadap lebar (L) butir beras. Lebar butir beras diukur antara punggung dan perut beras utuh menggunakan alat micrometer. ${ }^{13}$ Komponen-komponen sebagaimana yang dimaksud diatas dijadikan dasar dalam kontruksi pemidaan terhadap pelaku usaha yang diduga telah memperjualbelikan beras dibawah standar yang tela ditentukan pemerintah.

\footnotetext{
${ }^{13}$ Badan Standarisasi Nasional, 2008
} 
Tuntutan terhadap pelaku penjual dan mengedarkan beras campur diajukan karena orang yang melakukan tindak pidana tersebut telah menimbulkan kerugian konsumen sebagai pengguna beras. Perbuatan seseorang yang melakukan menjual dan mengedarkan beras campur tersebut dapat tidak dipidana apabila pelaku usaha tersebut memberikan informasi tentang keberadaan dari produk yang dihasilkannya kepada masyarakat tanpa harus menutup-nutupinya, baik dengan tulisan maupun dengan label tertentu sehingga masyarakat mengetahui dan tidak menjadi efek negatif apabila sipelaku usaha menjual dan mengedarkannya kemasyarakat luas.

\section{Kebijakan Perubahan SNI Beras Dari Sukarela Menjadi Wajib Dalam Pembuktian Tindak Pidana Mengedarkan dan Memperjualbelikan Beras Campur Dikaitkan Dengan Upaya Perlindungan Konsumen}

$$
\text { Pedagang beras umumnya }
$$
memiliki kebiasaan membeli beras berdasarkan asal gabah yang dibelinya. Asal-usul beras mendapat perhatian oleh pedagang beras. Alasan yang dikemukakan antara lain karena kepercayaan (mitra dagang) untuk menjaga kestabilan mutu beras yang diterimanya. Hampir semua pedagang tidak menjual beras dengan merknya sendiri - dengan alasan tidak ada keuntungannya, sementara konsumen sudah cukup percaya terhadap mutu beras yang ada.

Menurut penulis, prospek beras berlabel menunjukkan bahwa adanya beras berlabel SNI akan memberi dampak terhadap :

a. Penyediaan bahan pangan aman dan halal untuk dikonsumsi;

b. Pemberian kepuasan konsumen beras karena ada jaminan mutu beras bagi konsumen dalam dan luar negeri sehingga meningkatkan quota ekspor beras;

c. Memperpendek tataniaga beras atau mempermudah transaksi perdagangan beras sehingga memperlancar distribusi danpemasaran beras; dan

d. Peningkatan harga jual dan permintaan beras, sehingga harga gabah dan memberikan nilai tambah/ pendapatan bagi stakeholder dalam perdagangan beras seperti petani, penggilingan padi, pedagang beras dan rumah makan

Penerapan standar untuk produk beras di Indonesia belum dilakukan oleh produsen. Hal ini disebabkan minimnya 
pengetahuan produsen tentang standar produk beras, sebagai contoh produsen beras beranggapan bahwa tanpa memenuhi standar produk beras masih laku dijual di pasaran. Selain itu produsen beranggapan bahwa sertifikasi produk agar sesuai dengan standar atau SNI memerlukan biaya relatif tinggi. Standar Nasional Indonesia (SNI) merupakan standar tertulis berisi produk atau proses termasuk proses pengukuran yang menjadi acuan di Indonesia. Kegunaan SNI diuraikan sebagai berikut: memperlancar arus perdagangan, meningkatkan penerimaan produk Indonesia di luar negeri, memberikan perlindungan kepada konsumen dan masyarakat dalam aspek kesehatan, keselamatan, dan keamanan, mewujudkan tercapainya persaingan yang sehat dalam perdagangan, dan menunjang kelestarian lingkungan hidup.

Produk pertanian yang sudah memiliki sertifikasi sesuai SNI, berhak mencantumkan logo SNI tertentu dalam label kemasan produknya. Hal ini menjadi acuan bagi konsumen untuk memilih produk beras. Harapannya adalah konsumen dalam negeri maupun luar negeri memilih produk beras yang berlogo SNI pada label kemasannya. SNI mengacu kepada standar internasional
(ISO). Standar Nasional Indonesia (SNI) produk beras telah dibuat, namun penerapan label SNI pada produk beras belum ada. Pada produk beras, penerapan SNI masih bersifat sukarela. Bagi perusahaan produsen beras yang berkeinginan menggunakan logo SNI beras untuk meningkatkan jaminan mutu kepada konsumen tetapi masih sulit memperoleh label SNI karena kebijakan pemerintah baru memikirkan jangka pendek (membentuk Otoritas Kompetensi Ketahanan Pangan/OKKP), sehingga belum ada Lembaga sertifikasi produk (LSPro) dan Laboratorium pengujian beras yang terakreditasi.

Produk beras di Indonesia belum memiliki standar produk beras yang mengacu kepada standar nasional (berlogo SNI) maupun internasional. Hal ini menyebabkan produk beras dalam negeri sulit bersaing dengan produk beras luar negeri, akibatnya konsumen dalam negeri ragu untuk menggunakan produk beras lokal. Salah satu upaya untuk mewujudkan standar produk beras adalah adanya infrastruktur kelembagaan yang mengeluarkan kebijakan standar bagi produk beras. Untuk memperoleh sertifikasi tidak selalu melalui BSN (Badan Stndardisasi Nasional), tetapi juga melalui Deperindag, Balai Riset Industri 
dan Standardisasi, Depkes, BPOM, dan Departemen Pertanian.

$$
\text { Departemen }
$$

Pertanian/ Kementerian Pertanian sebagai wakil pemerintah dalam bidang pertanian belum memiliki lembaga sertifikasi produk (LSPro) dengan lingkup gabah dan beras. LSPro merupakan lembaga independen yang bertugas memberikan sertifikasi produk berdasarkan standar tertentu melalui Komite Akreditasi Nasional (KAN) di BSN. LSPro dengan lingkup beras memberikan sertifikasi memerlukan data-data hasil pengujian berkaitan dengan produk beras. Oleh karena itu LSPro biasanya merekomendasikan laboratorium uji terakreditasi yang mempunyai ruang lingkup mutu beras untuk memeriksa dan menguji beberapa komponen yang diperlukan untuk memenuhi standar produk beras. Di lingkup Departemen Pertanian, tidak semua laboratorium uji sudah terakreditasi, oleh karena itu diperlukan laboratorium uji produk beras yang terakreditasi. Jika LSPro dan laboratorium uji lingkup mutu beras sudah terbentuk, maka beberapa produk beras bisa diajukan untuk mendapatkan sertifikasi yang menyatakan bahwa produk tersebut sudah memenuhi SNI.
Lebih jauh, produk beras Indonesia mampu bersaing dengan produk beras baik di dalam negeri maupun di luar negeri. Konsumen di Indonesia bangga dan percaya terhadap produk beras dalam negeri karena mendapat jaminan mutu dari produsen beras. Cara untuk mendapatkan sertifikasi mutu beras di Indonesia saat ini dapat diperoleh melalui 3 cara, yaitu mengacu berdasarkan kemurnian varietas, keamanan pangan atau persyaratan mutu Standar Nasional Indonesia (SNI).

\section{Penerapan Standar Nasional}

Indonesia dapat lebih berdaya guna dan berhasil guna jika didukung dengan sistem sertifikasi, pengujian dan kalibrasi yang andal, dapat dipercaya dan dilakukan sesuai dengan aturanaturan yang berlaku secara internasional. Dengan demikian lembaga sertifikasi dan laboratorium pengujian/ kalibrasi mempunyai peran yang sangat besar dalam memberi jaminan mutu terhadap barang dan atau jasa. Dengan adanya jaminan mutu yang didukung oleh sistem sertifikasi, pengujian dan kalibrasi akan meningkatkan kepercayaan internasional terhadap barang dan / atau jasa Indonesia, sehingga mambantu upaya peningkatan kepercayaan konsumen di dalam negeri dan ekspor di Indonesia. Kegiatan 
sertifikasi pengujian dan kalibrasi dilakukan oleh lembaga sertifikasi dan laboratorium yang telah diakraditasi oleh KAN (Komite Akreditasi Nasional), baik yang berlokasi di dalam dan di luar negeri. Semua peraturan dan persyaratan tentang sertifikasi di sektor pertanian mengacu pada persyaratan dalam Pedoman BSN (Badan Standarisasi Nasional) atau KAN yang sesuai dengan ruang lingkup sertifikasi.

Lembaga sertifikasi dan atau Laboratotium yang telah terakreditasi oleh KAN berhak melakukan kegiatan sertifikasi dan atau kegiatan pengujian/ kalibrasi dan menerbitkan sertifikat, sesuai dengan lingkup akreditasinya. Untuk menerbitkan sertifikat dari produk berlabel, bernomor SNI (Standar Nasional Indonesia) dapat dilakukan oleh Lembaga sertifikasi Produk (LSPro) dengan mengacu pada data hasil pengujian yang dikeluarkan oleh Laboratorium yang ruang lingkupnya telah terakreditasi. Hal ini dapat dilakukan untuk memberi Nomor SNI beras. Manfaat menerapkan SNI adalah :

a. Mendukung terciptanya persaingan dagang yang sehat antar perusahaan;

b. Memberikan perlindungan kepada masyarakat; c. Menjamin tertib hukum dagang dalam hal mutu produk, sehingga menunjang kelancaran arus barang;

d. Mewujudkan jaminan mutu dengan memperhatikan sektor terkait;

e. Meningkatkan daya guna, hasil guna dan produktifitas dalam mencapai mutu produk / jasa yang memenuhi standar; dan

f. Dapat menunjang kelestarian lingkungan hidup.

Beras yang ada di pasaran umumnya sudah berlabel, tetapi tidak sesuai dengan persyaratan kaidah sistem pelabelan produk pangan, akibatnya konsumen dirugikan dan belum ada tindakan sanksi hukum dari pihak pemerintah. Respon konsumen rumah tangga dan rumah makan umumnya belum percaya pada beras berlabel, namun konsumen bersedia membeli bila ada beras berlabel SNI. Pedagang beras umumnya kurang terpengaruh terhadap beras berlabel karena tidak menggunakan merk sendiri dan merk mengikuti keinginan konsumen, walaupun tidak sesuai isinya. Penggilingan padi umumnya berminat menggunakan label kemasan SNI beras, namun belum ada mekanisme mendapatkan label SNI beras, 
sehingga pelabelan beras belum memenuhi persyaratan.

Beras Campur Dikaitkan Dengan Upaya Perlindungan Konsumen bahwa status SNI yang masih bersifat

\section{KESIMPULAN}

Dari hasil penelitian dan pembahasan yang telah penulis lakukan, maka penulis dapat menyimpulkan sebagai berikut :

a. Pembuktian Tindak Pidana Mengedarkan, dan

Memperjualbelikan Beras Campur bahwa penyidikan yang telah dilakukan oleh Penyidik dalam rangka penanganan perkara tindak pidana perlindungan konsumen dalam hal ini mengedarkan dan memperjualbelikan beras campur dapat dilanjutkan dikarenakan ditemukannya alat bukti berupa adanya dokumen perjanjian dari para pihak, peraturan yang mengatur tentang mengedarkan dan memperjualbelikan beras campur yang belum memberikan kepastian hukum sehingga upaya dalam memberikan perlindungan terhadap masyarakat khususnya konsumen dalam hal mengedarkan dan memperjualbelikan beras campur

b. Kebijakan Perubahan SNI Beras Dari Sukarela Menjadi Wajib Dalam Pembuktian Tindak Pidana Mengedarkan dan Memperjualbelikan sukarela menjadi celah hukum bagi pelaku usaha untuk melakukan perbuatan curang, untuk itu perlu ditingkatkan kasusnya menjadi wajib sehingga harus ditaati oleh para pelaku usaha sehingga memberikan kepastian hukum terhadap jaminan perlindungan konsumen

\section{REFERENSI}

\section{Buku}

Ahmadi Miru \& Sutarman Yodo, Hukum Perlindungan Konsumen, PT Raja Grafindo Persada, Jakarta, 2004

Agussalim Andi Gadjong, 2007, Pemerintahan Daerah (Kajian Politik dan Hukum), Ghalia Indonesia, Bogor,

Ahmad Mujahidin, 2007, Peradilan Satu Atap di Indonesia, Refika Aditama, Bandung,

Arbi Sanit, 1985 Perwakilan Politik di Indonesia, Rajawali, Jakarta,

Barda Nawawi Arief. 2010, Kapita Selekta Hukum Pidana, Citra Aditya Bakti, Bandung, 
2008. Masalah

Penegakan Hukum dan

Kebijakan Hukum Pidana

Dalam Penanggulangan

Kejahatan, Kencana, Jakarta,

Aspek Kebijakan Penegakan

dan Pengembangan Hukum

Pidana, PT. Citra Aditya

Bakti, Bandung,
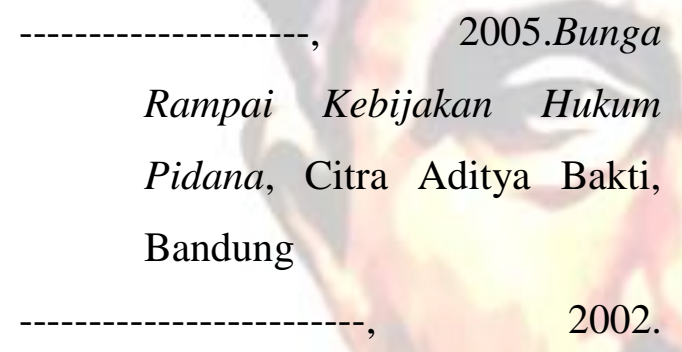

2002.

Kebijakan Hukum Pidana, PT.

Citra Aditya Bakti, Bandung,

Bambang Sunggono. 2005,

Metodologi Penelitian Hukum,

PT. Raja Grafindo, Jakarta,

C.S.T Kansil, dan Christine S.T.

Kansil, 2002. Hukum dan Tata

Negara Republik Indonesia,

Cetakan Ketiga, Rineka Cipta,

Jakarta,

Eddi Wibowo, dkk. 2004, Hukum dan

Kebijakan Publik, Yayasan

Pembaruan Administrasi

Publik Indonesia, Yogyakarta,

Happy Susanto, 2008. Hak-Hak

Konsumen Jika Dirugikan,

Visimedia, Jakarta,
Husni Syawali, dan Neni Sri Imaniyani ed 2000, Hukum Perlindungan Konsumen, Bandung, Mandar Maju,

Kadri Husin, 1999 . Diskresi Dalam Penegakan Hukum Pidana di Indonesia, Fakultas Hukum Universitas Lampung, Bandar Lampung,

Masri Singarimbun dan Sofian Effendi, $1987 \quad$ Metode Penelitian Survai, Yokyakarta, Moh.Hatta, Beberapa Masalah Penegakan Hukum Pidana Umum dan Pidana Khusus, Liberty Yogyakarta, 2009

Moh. Hatta 2010, Kebijakan Politik Kriminal, Pustaka Pelajar, Yogyakarta,

M. Solly Lubis, Filsafat Ilmu dan Penelitian 1994, Bandung, Mandar Maju,

Sudarto 2007, Hukum dan Hukum Pidana, Alumni, Bandung,

Susanti Adi Nugroho 2008, Proses Penyelesaian Sengketa Konsumen Ditinjau dari Hukum cara Serta Kendala Implementasinya, Kencana, Jakarta, 
Teguh Prasetyo 2010, Hukum Pidana,

Edisi Revisi, Raja Grafindo

Persada, Jakarta,

Wirjono Prodjodikoro, 2003 Asasasas Hukum Pidana Indonesia Edisi Ketiga, Refika Aditama, Bandung,.

\section{Peraturan Perundang-Undangan}

Undang-Undang Republik Indonesia

Nomor 8 Tahun 1981 tentang

Hukum Acara Pidana

Undang-Undang Republik Indonesia

Nomor 8 tahun 1999 tentang

Perlindungan Konsumen.

Undang-Undang Republik Indonesia

Nomor 36 tahun 2009 tentang

Kesehatan.

\section{Kamus}

Departemen Pendidikan Nasional,

Kamus Besar Bahasa

Indonesia Edisi Ketiga, Balai

Pustaka, Jakarta, 2005,

Setiawan Widagdo. 2012, Kamus

Hukum, Prestasi Pustaka,

Jakarta,

Sudarsono. 2007, Kamus Hukum,

Rineka Cipta, Jakarta 